\title{
CAUSA GRATIAE - THEOLOGICAL ANALVSIS OF AUGUSTINE'S ON GRACE AND FREE WILL
}

Augustine is unanimously considered to be the greatest church father of western Christianity. His major theological controversy was against Pelagianism, a Christian heresy identifying God's grace with His endowment of man with free choice in creation. When challenged to address the issue of juxtaposition of God's grace and human free choice, Augustine responds by writing On Grace and Free Will, where he opens his discussion by the proof of free choice. Further in the argument, however, he definitely abandons this notion and moves towards lifting up and praising the primacy and sole agency of the activity of God's grace.

\section{Introduction}

Aurelius Augustinus (354-431) not only lived in a time when the basic teachings of Christianity were being formulated, but also substantially contributed to this development. The assessment of this prominent figure of late $4^{\text {th }}$ and early $5^{\text {th }}$ century western Christianity has to take place in the light of the situation amid which he worked and the responsibility which he held, presuppositions that influenced his mode of thinking and the theological controversies that shaped the content of his thought. [1] Of the three major theological controversies we will focus our attention on the challenge of Pelagius and his later followers, which stirred the most crucial question of western Christianity - of human sinfulness and the priority of God's acting grace. At the very climax of this controversy Augustine was visited by two monks from a monastery, where a commotion arose concerning the relationship between free will and the necessity of grace for man's salvation. As a result, accompanied by two letters of explanation, Augustine not only instructed the two brothers but also wrote a treatise entitled On Grace and Free Will.

\section{Augustine versus Pelagianism}

Before we move into analysis of the treatise, it is necessary to come to know the Pelagian movement as such. First, we will look at the reasons behind the rise of the movement, followed by assessment of its main theological thrust. The impetus for the movement was "a protest against the decay of Christian morals." [3] Christianity, being well established due to the last one hundred years of being the official religion of the Roman Empire, was no more a community of strict morals and courageous confessions so characteristic of previous centuries. Rather, it included a "large number of converts whose Christianity can hardly have gone deeper than acceptance of baptism and profession of the name." [3] Pelagius, too, saw the decline and decided to act. Peter Brown summarizes the basic thesis of Pelagius' manifesto: "This message was simple and terrifying: since perfection is possible for man, it is obligatory." [1] "God," Brown continues the summary, "commanded unquestioning obedience,... man's nature had been created for such perfection to be achieved.” [1]

Pelagianism, first of all, made a fundamental theological claim for the justice of God. Next, it placed the power in human nature, the responsibility on human shoulders, and equated grace with God's endowment in creation. The logic went as follows: Since God is just, He will judge justly. In His justice, "God has endowed his creature with a capacity (possibilitas) or ability (posse) for action, and it was for him to use it." [4] Man was thus endowed - by the grace of God given in creation - with posse, and now it was his job to actualize it in velle and finally in esse. In summary, the primal endowment of man with free will, the revelation of the law, the teaching of the gospel, the forgiveness of past sins in baptism and the example of Christ were all given so that man might, and therefore must, realize (esse) all the precepts ordained to him by God. [2]

Augustine sensed and exposed the inherent dangers of this position: Sin was perceived only as an imitation of Adam, the first sinner; man was called to overcome this bad habitus of imitation. In the Fall, human nature underwent no substantial change, therefore needed not to be redeemed. Man was emancipatus a Deo, and was more and more to become so, with sufficient freedom and self-control to achieve for himself blessedness. God's grace outside the process of creation was nonexistent and played no active role in salvation. The proclaimed perfection of an individual, when achieved, was claimed meritorious; thus resulting in denying the necessity and the redeeming work of Christ. Augustine knew well that the concept of perfect obedience by which punishment can be avoided and grace earned is not only impossible, but also detrimental to Christian message as a whole.

\footnotetext{
* Tomáš Gulán

Evangelical Theological Faculty, University of Comenius, Bratislava, Slovakia, E-mail: tgulan@yahoo.com
} 


\section{Summary of the Argument of On Grace and Free Will}

Augustine observes that there are "some persons who so defend God's grace as to deny man's free will, or who suppose that free will is denied when grace is defended." [4] We can see here two issues stated. First, the question of grace when it is so emphasized as to destroy free human choice, with the conclusion of determinism and libertinism. He warns to stay on the straight path and not to decline to the "left" of forsaking the good way of life. Second, there is the danger of turning to the "right" by attributing to oneself those good deeds done by the power of the grace of God previously freely given. Against this distortion, crowned by the Pelagian notion of merit, Augustine warns in the treatise as a whole.

This paper, however, wants to engage a step deeper into Augustine's argument. There is certainly more to Augustine's rhetoric than just this simple mingling together of grace and human will. When the work is taken as a whole, as one solid case, then Augustine's opening discussion of free will serves only as a rhetorical tool aimed at destroying this very starting point of the case for human free will. He achieves so by making it obsolete within the framework of the treatise as a whole, which is at last aimed not at the argument for upholding free will, but for upholding and praising solely the grace of God. At last, the opening proof, when encountered by effective grace and acting God, is superseded, and the only thing left to do is to stand in awe at the great mysteries of God.

\section{Observation of Augustine's Proof of Free Will}

For the purpose of our study it is not necessary to cover every aspect of the treatise. In this part we will rather focus only on the opening part, the argument for free will, which will lead us to understand the key facets of the overall shift to be exposed further below. Augustine's opening statement reads as follows:

Now He has revealed to us, through His Holy Scriptures, that there is in man a free choice of will... There is, to begin with, the fact that God's precepts themselves would be of no use to a man unless he had free choice of will, so that by performing them he might obtain the promised rewards. For they are given that no one might be able to plead the excuse of ignorance. [4]

Two things are worth noticing here. First, as already mentioned above, Augustine begins by an attempt to prove the existence of free will, so the discussion is placed on the academic level, without personal engagement of the party making the claim. The proof he provides is the logic of the existence of the precepts and commandments of God, expressly adapted to the human will. This leads him to conclude not only the unquestionable existence of human freedom, but also to accuse everyone. Man has no right to call for an excuse on his ignorance, but must attribute all fault for evil actions to himself. This is the second point, namely the consequent accountability of man for his conduct and for the results of his actions. Responsibility for evil rests wholly on men's shoulders and it is we who are to be blamed for evil and are convicted as inexcusable. Augustine concludes, "No man, therefore, when he sins, can in his heart blame God for it, but every man must impute the fault to himself." [4]

So much for the classical philosophical argument for free will, both resulting from and leading to human responsibility. The most important striking point of the opening part of the treatise is that not only is the whole argument based on the call for human responsibility, thus on law, but that it is void of Christ. Actually, Christ does appear one time only in these four chapters, but even then He serves as a threat of judgment for the one who does not have faith in Him. Thus, if the treatise were to end with chapter five, it would provide the reader with a logical argument for the existence of free will in man, but consecutively would leave him only with the accusation and condemnation of the most severe law, with no mercy for the convicted sinner.

\section{Examination of Augustine's Argument as a Whole}

Augustine, however, does not end at the point of establishing human freedom and indispensable condemnation of a sinner. $\mathrm{He}$ moves on to build up an argument for the necessity of cooperation of grace with human will. In his discussion Augustine introduces, among many others, three further important points, to be examined below.

\subsection{Against the Pelagian notion of merit by showing the prevenience of grace}

For his argument against the notion of merit, Augustine chooses to look at the Apostle Paul. It is in this discussion where the two primary biblical texts (John 15:5 and 1 Corinthians 4:7) are used as the leading argument. Showing the absurdity of Pelagian cause, he writes, "Now there was, no doubt, a decided merit in the Apostle Paul, but it was an evil one." [4] After all, Paul himself confesses that by the grace of God he is what he is and in the good activity it was not he himself alone, but the grace of God with him.

Augustine hence shows that it is grace by which our works are always preceded. The rhetorical method applied includes:

- Always to place the two subjects (grace and human will) in juxtaposition to each other, where these two always follow one after another.

- The latter not only stands in opposition to the former, it replaces the primacy of the former and thus places the major emphasis on the latter.

- When the resulting action is good, the latter of the two is always the grace of God; when the resulting activity is evil, the latter agent is man and his choice.

A few examples to illustrate:

- Grace is not preceded by our good deserts, but by evil ones.

- Love, which fulfills the commandments, is not of ourselves, but of God.

- We would not love God unless He first loved us.

- There can be no merit in man's choice of Christ, rather grace is always prevenient. 
Consequently, whenever one talks of good action, it is always God's grace that has overcome the evil human agent. Subsequently, whenever the human agent acts evil no more, it is due to grace, which has necessarily preceded.

\subsection{Reexamination of the case for human responsibility}

As already noted, Augustine retains the emphasis on human responsibility. When he returns to the subject almost at the very end of the treatise, he no longer responds to the challenge of moral negligence, but he makes a frontal attack on Pelagianism. Augustine not only argues for the sheer gratuitousness of grace, but all the more he illustrates it on the example of infant baptism, so despised by his opponents. He furthermore calls on Romans 9 , declaring the universal sinfulness, and just like apostle Paul, he too does not reason anymore, but only stands in awe at the depth of the wisdom and the riches of God. Augustine subsequently finishes his case with the following, "But grace, indeed, effects this purpose - that good works should now be wrought by those who previously did evil... Their language, therefore, ought not to be: "Let us do evil that good may come;" but: "We have done evil, and good has come..." [4]

As a result, human responsibility is retained, this time however not on the basis of the threat of the law, but by the previous-ness of the grace of God. And there is one more difference on top of this. This time the reader is not left alone in despair over his inability and failure as was the case at the end of the opening four chapters, but is given all the good that has come despite all our evil merits. Augustine thus suggests, as the only proper human response to the gratuitously given grace, to praise and to make a confession face-to-face with the good Giver Himself.

\subsection{Towards the absolute activity of the grace of God}

The more one proceeds in reading On Grace and Free Will the more one is driven to the activity of God. The grace of God is causa sine qua non of "the fulfillment of the law, and the liberation of nature, and the removal of the dominion of sin." [4] The opening hermeneutics of law as that which must be fulfilled is turned 180 degrees around, exemplified by following: "But God commands some things which we cannot do, in order that we may know what we ought to ask of Him." [4] The sum of Augustine's argument concerning our willing sounds perplexing, but his aim for the primacy of God in all our good willing is unambiguous. He writes, "It is certain that it is we that will when we will, but it is $\mathrm{He}$ who makes us will what is good," [4] and,

He operates, therefore, without us, in order that we may will but when we will, and so will that we may act, He co-operates with us. We can, however, ourselves do nothing to effect good works of piety without Him either working that we may will, or co-working when we will. Now concerning His working that we may will, it is said: "It is God which worketh in you, even to will." (Phil. ii. 13) [4]
To conclude the argument as a whole, Augustine combats the Pelagian writings and the darkness in them that says that "Love comes to us from our own selves." [4] Augustine's work ends with unequivocal statements about the wills of men being in the power of God, with God operating on men's hearts to incline their wills howsoever He pleases. In similar line, his closing discussion of the hardening of Pharaoh's heart and the church's practice of infant baptism can be said to provide an un-verbalized confutation of his own opening argument shown to be equal to his Pelagian opponents'.

In the end On Grace and Free Will does not offer a logical explanation neither of evil in the world nor the gratuitousness of the grace of God. It limits man's power not to render inside the secret judgments of God, and rather calls to "give God the praise" and "pray for understanding," crowned with a final doxology and Amen to our "Lord and Savior Jesus Christ, to whom belongs the honor, and the glory, and the kingdom, with the Father and the Holy Ghost, for ever and ever.” [4]

\section{Conclusion}

Augustine, more than any other Christian theologian for a number of centuries, makes the case for the inability of the law - being it given or revealed - and/or human will to grant salvation. If one were to follow his opponents' theology - clear-cut Pelagianism - the human contribution would be the all important impetus of our salvation. If one were to follow later developed semi-pelagian way of thought, both human conduct and the grace of God remain necessary and active in the process of one's salvation. If one were to follow Augustine, as we have traced in this examination, the human input remains a necessary premise, but not only is it not effective without the necessary coming of grace, but also by the coming of grace human impetus - exemplified by the notion of free will - becomes obsolete. Finally, but this is beyond the scope of Augustine as well as this paper, if one confesses the sole activity of God from the very beginning, if "we proclaim Christ crucified, a stumbling block to Jews and foolishness to Gentiles," the human presuppositions have no place whatsoever, and the whole sum of our reasoning and argumentation is guided solely by confession and doxology.

Augustine, living at the threshold of this debate, was not equipped to make the full theological step towards the all powerful activity of God in man's salvation; thus he was apt to the distortion of semi-pelagian concept of meritorious works. He, however, laid the foundation and prepared the way for the debate climaxing in the Reformation's doctrine of sola gratia. Only then, as, for example, in Luther's work The Bondage of the Will, were certain questions - such as one of the freedom of human will in attaining one's salvation - definitely declared as misleading and placed outside of realm of man facing the all powerful and merciful God. There, finally, in line with Christian creed, one confesses the sole grace of God in Christ alone. 


\title{
References
}

[1] BROWN, P.: Augustine of Hippo, A Biography, University of California Press, 2000.

[2] KELLY, J. N. D.: Early Christian Doctrines, Continuum, 1958.

[3] Library of Christian Classics, vol. VIII, Westminster, 1953.

[4] AUGUSTINE: On Grace and Free Will, The Nicene and Post-Nicene Fathers, vol. V., Eerdmans, 1997.

\section{UNIVERSITY OF ŽILINA}

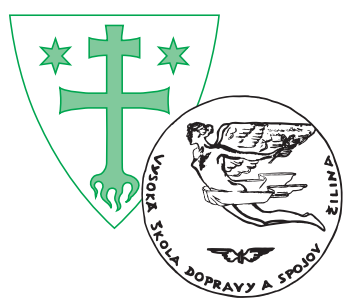

\section{TRANSCOM 2007}

\section{$7^{\text {th }}$ EUROPEAN CONFERENCE OF YOUNG RESEARCH AND SCIENCE WORKERS}

\author{
Contact address: \\ Ing. Vrablova \\ Univerzitna 8215/1
}

01026 Zilina, Slovak Republic

Tel.:+421-41-5135141, Fax: +421-41-5135052

E-mail: vrablova@nic.utc.sk

Information on the Conference can be found at: www.transcom2007.sk 